\title{
Determinisme Teknologi dalam Teknologi Komunikasi dan Informasi
}

\author{
Teguh Ratmanto
}

\begin{abstract}
Technological determinism, as the result of technology innovation, raised a constant debate among scholars concerning its position toward the society: whether it was caused by the society, or the effect of social change. This debate, in the end, produced two kinds of party: those who support technology, and those who against it, both the optimists or the pessimist one. Those who against technology believed that technology in no other way was created by society. The supporter, reversely, strongly believed that technology shaped society, even determine the future. Both party believed there is interplay between technology and society.
\end{abstract}

Kata kunci: determinisme teknologi, teknologi, masyarakat

\section{Pengantar}

Berdasarkan catatan sejarah, homo sapiens telah hidup di bumi selama ratusan abad. Mereka telah menghabiskan ribuan tahun dengan cara hidup berpindah-pindah dari satu tempat ke tempat lain dengan hanya menggunakan peralatan yg sangat sederhana. Dalam kaitannya dengan penggunaan teknologi, menurut Winston (1999), ada tiga revolusi teknologi yg memiliki dampak yang sangat penting dalam kehidupan manusia. Pertama adalah revolusi pertanian pada sekitar 8000 SM. Pada masa itu nenek moyang kita mulai menetap di suatu tempat dan mulai menghasilkan peradaban yang didasarkan pada ekonomi agrikultural. Yang kedua, revolusi industri yang terjadi sekitar abad ke-18 di Eropa. Pada masa itu, tenaga otot digantikan oleh tenaga mesin uap yg dihasilkan dari hasil pembakaran batubara dan kemudian dengan mengunakan bahan bakar minyak. Revolusi industri ini mengakibatkan terjadinya pergeseran struktur masyarakat dari masyarakat agrikultur ke masyarakat industri yg berlandaskan ekonomi industri. Yang ketiga adalah revolusi informasi dimulai pada sekitar akhir abad ke-20. Sekarang ini, informasi dianggap sebagai komoditas utama, menggantikan produk-produk industri.

Revolusi-revolusi yang digerakkan oleh teknologi ini memiliki dampak yg sangat besar pada struktur masyarakat. Kemunculan masyarakat agrikultur, industri, dan terakhir informasi, merupakan bukti yang tak terbantahkan dari klaim bahwa teknologi mempengaruhi perubahanperubahan besar dalam kehidupan sosial kemasyarakatan. Masyarakat-masyarakat ini dianggap sebagai konsekuensi logis dari inovasiinovasi teknologi yg mendahuluinya.

Inovasi-inovasi teknologi dalam bidang komunikasi juga telah membawa perubahan masyarakat. Penemuan mesin cetak pada abad ke15, misalnya, telah menjadikan akses ke pengetahuan menjadi lebih terbuka bagi 
masyarakat umum, yang sebelumnya hanya dikuasi oleh sekelompok kecil elit anggota masyarakat. Dampak dari penyebaran pengetahuan yang meluas ini dapat dilihat beberapa abad kemudian, yaitu munculnya revolusi industri yang secara dramatis telah mengubah struktur masyarakat, dari masyarakat pertanian menjadi masyarakat industri. Penemuan telegrap telah mengubah kecepatan pengiriman dan penyebaran berita. Radio, televisi, dan komputer, telah mengubah wajah dunia. Menurut Kern yang dikutip oleh Cooper, (2002, 89), “... the first communication technologies, newspaper, telephones and telegraphs, allowed a greater sense of simultaneity, where a sense of the global first become apparent. The sense of the present was thickened when large number of people felt they were experiencing the same events."

Teknologi komunikasi memiliki dampak pada homogenitas pengetahuan dan rasa 'keduniaan' (worldness) yang merupakan ruh globalisasi. Sekarang ini, hampir setiap orang menyadari bahwa mereka tinggal di dunia yang sama, di mana televise, radio, media cetak, dan internet, berfungsi sebagai 'jendela dunia.' Dunia kini telah menjadi sebuah 'kampung dunia' di mana setiap orang dapat saling mengenal melalui teknologi komunikasi.

Menurut Cooper (2002, 13-14), In other words, the quantitative change in technological mediation also entails a qualitative change. If, within modernity, the broadcast news of the world made an impact on local community, then the social formation remained largely constituted within a less abstract modality than that governed by extended media relations. Within, postmodernity, however, the increase in media and communication technologies means that social integration is increasingly carried out at level of disembodied-extended less concrete modalities.

Diskusi seputar hubungan antara teknologi dan masyarakat, khususnya teknologi informasi dan komunikasi, telah menjadi wacana yang mengundang para pakar dari berbagai disiplin ilmu untuk terlibat di dalamnya. Tema pokok dari perdebatan ini adalah apa yang merupakan penggerak utama sebuah peruabahan sosial. Teknologi atau masyarakat. Mereka yang meyakini teknologi sebagai penggerak perubahan bisa dikategorikan sebagai pendukung determinisme teknologi dengan determinisme media sebagai varian utamanya.

Di sisi lain, mereka yang meyakini bahwa masyarakatlah yang penggerak utama perubahan, menolak gagasan determinisme teknologi. Tulisan ini akan membahas determinisme teknologi, khususnya dalam bidang komunikasi dan informasi, sebagai salah satu mazhab pemikiran yg cukup terkenal.

\section{Diskusi Seputar Determinisme Teknologi}

Determinisme tekhnologis adalah turunan dari determinisme. Secara garis besar, mereka yang menentang determinisme teknologi, secara teoretis, dapat dikategorikan sebagai kaum 'social construction.' Mereka cenderung melihat teknologi dari sudut pandang material semata. Teknologi hanya dilihat sebagai alat atau mesin. Teknologi, bagi mereka, tidak lebih dari sekadar mesin yang penggunaannya ditentukan oleh manusia. Mereka menempatkan manusia sebagai aktor utama di dalam perubahan sosial. Mereka cenderung meyakini bahwa roda sejarah tidak digerakkan oleh mesin, tetapi digerakkan oleh orang-orang besar, yang memiliki kharisma pengaruh yang besar pada masyarakat luas.

Di sisi lain, ada sudut pandang yang sama sekali berbeda, yaitu determinisme teknologi. Para pendukung determinisme teknologi meyakini bahwa teknologi, baik secara langsung maupun tidak langsung, merupakan penggerak utama roda perubahan sosial. Baik diakui atau pun tidak, teknologi memiliki kaitan yang erat dengan masyarakat. Secara teoretis, mereka yang meyakini determinisme teknologi dapat dikelompokkan menjadi kaum optimis dan pesimis.

Di samping dua sudut pandang ini, Feenberg (1996) menyebutkan dua teori tentang teknologi, yaitu instrumental dan substantif. Teori instrumental memiliki dasar pemikiran bahwa teknologi adalah 


\section{Bagan 1 \\ Skema Disksusi Seputar Determinisme Teknologi}

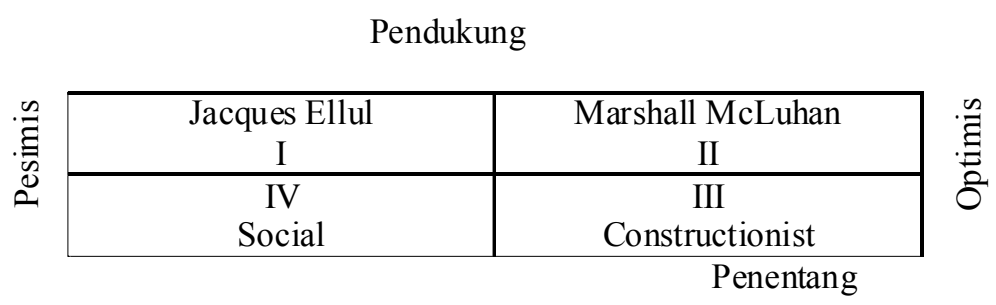

'alat' yang senantiasa siap untuk melayani kepentingan pemakainya, sedangkan teori substantif memiliki keyakinan bahwa teknologi bersifat dinamis dan mampu mengubah kehidupan sosial.

Secara sederhana peta diskusi seputar determinisme teknologi dapat digambarkan sebagai mana bagan 1 .

Peta diskusi seputar determinisme teknologi ini secara sederhana dapat digambarkan pada tabel di atas. Tabel ini memiliki empat ruang yang disebut kuadran. Kuadran I dan II yang terletak di atas sumbu $X$, menunjukkan sikap mendukung keyakinan determinisme teknologi, sedangkan kuadran III dan IV yang terletak di bawah sumbu $\mathrm{X}$, menunjukkan sikap yang menentang determinisme teknologi. Sementara itu, kuadran I dan IV menunjukkan sikap yang pesimis terhadap teknologi, sedangkan kuadran II dan III menunjukkan sikap optimis.

\section{Keberatan terhadap Determinisme Teknologi}

Mereka yang menentang determinisme teknologi mengajukan argumen bahwa teknologi adalah produk kultural dan sosial masyarakat, oleh karena itu teknologi diciptakan untuk memenuhi kebutuhan manusia. Tidak ada teknologi yang tercipta secara tidak sengaja. Teknologi diciptakan dengan tujuan untuk menjadikan hidup yang lebih mudah, nyaman, dan lebih baik. Pada awal penciptaannya, teknologi dirintis dan dikembangkan oleh para jenius seperti, Edison, bell, atau Marconi. Sekarang ini, teknologi dikembangkan oleh para peneliti di laboratorium.

Pada intinya, kaum penentang determinisme teknologi ini meyakini bahwa teknologi adalah hasil rekayasa masyarakat, oleh karena itu, masyarakatlah yang menjadi penentu teknologi. Komputer, misalnya, hanyalah kombinasi dari plastik, logam, dan peralatan elektronik. Tidak ada yang dapat dilakukan oleh komputer. Tanpa software, komputer hanyalah sebuah alat aneh yang terletak di atas meja di ujung kamar. Pertanyaannya adalah siapa yang membuat computer dan juga software-nya. Pada intinya, masyarakat memiliki peranan yang lebih dominan ketimbang teknologi.

\section{Pendukung Determinisme Teknologi}

Di sisi lain, para pendukung determinisme teknologi yang secara teoretis dapat dikelompokkan ke dalam dua aliran utama, yaitu mereka yang optimis dan pesimis. Meskipun demikian, keduanya meyakini bahwa teknologi dapat mengubah masyarakat. Bahkan pada titik tertentu dapat menentukan masa depan masyarakat. Menurut Mesthene pendapat yang optimistis terhadap teknologi ini dapat dilacak hingga ke optimisme ilmu pengetahuan pada abad ke-19. Lebih lanjut Mesthene (1970: 16) mengatakan, "This view has its modern origins in the Baconian conception of knowledge as power, in the social philosophies such nineteenth-century thinkers as Saint-Simon and August Comte," 
sedangkan pandangan mereka yang pesimis, masih menurut Mesthene (1970, 17), “... is heir to two different traditions. It is akin to historical 'back-to-nature' attitudes toward the world, such as we associate with Jean Jacques Rousseau and Henry Thoreau. It also derives from traditional socialist critiques of the appropriation of technology as capital."

Satu varian determinisme teknologi adalah determinisme media dari Marshall McLuhan sebagai salah satu tokohnya. Frase yang sangat terkenal dari McLuhan adalah 'the medium is the messsage'. Media yang digunakan untuk menyampaikan pesan, menurut McLuhan, bukan hanya sekadar alat, tetapi memiliki peranan yang tertentu. Masyarakat tidak hanya dipengaruhi oleh 'isi' tetapi juga dipengaruhi oleh 'media' yang digunakan. Buku, misalnya, memunculkan dampak pola pikir yang linier dan analitis. Buku mengajarkan cara berpikir linier karena ia mendidik masyarakat untuk berpikir searah dari kiri ke kanan (atau sebaliknya), di samping itu, juga mengajarkan berpikir analitis, karena buku terbagi ke dalam beberapa bab, yang tiap babnya terdiri dari paragraf, yang tersusun dari kalimat, dan kalimat ini tersusun dari kata-kata, dan kata-kata tersusun dari huruf-huruf. Perubahan pola pikir ini yang 'diajarkan' oleh buku ini telah mengubah struktur kognitifmasyarakat.

Senada dengan pendapat McLuhan, Innis meyakini bahwa media mempunyai peranan yang penting di dalam perubahan masyarakat. Menurut Innis, seperti yang dikutip oleh Galvin (1994:180),

"A medium of communication has an important influence on the dissemination of knowledge over space and time.. According to its characteristics it may be better suited to the dissemination of knowledge over time than over space, particularly if the medium is heavy and durable and not suited to transportation, or to the dissemination of knowledge over space than over time, particularly if the medium is light and easily transported. The relative emphasis on time or space will imply a bias of significance to the culture in which it is embedded."

Media, menurut Innis, bukanlah hanya sekadar alat. Kehadiran media sendiri telah memiliki dampak pada keseluruhan proses penyebaran pengetahuan atau pesan. Tiap media memiliki bias atas ruang dan waktu. Media yang berbeda akan memiliki dampak yang berbeda pula. Hal ini karena, bukan hanya isi saja yang memiliki bias, tetapi juga medianya. Mediayang terikat-pada-ruang (spacebinded) memunculkan masyarakat yang memiliki tradisi oral. Salah satu ciri tradisi oral adalah hadirnya kelompok kecil masyarakat yang memiliki hak istimewa dalam menafsirkan pengetahuan. Sebaliknya media-media yang terikat-pada-waktu (time-binded) memiliki dampak pada munculnya masyarakat yang cenderung egalitarian yang berakar pada budaya tulisan. Pada masyarakat ini, setiap orang memilki hak yang sama atas akses terhadap pengetahuan, sehingga pada masyarakat yang seperti ini, tidak akan ada lagi kelas sosial khusus yang memiliki hak sebagai satu-satunya penafsir pengetahuan. Lebih jauh lagi, Galvin (1994:180-181) menyebutkan, "Whereas print solved the problem of producing standardized communication rapidly and in sufficient quantities to administer large areas, the development of electronic communication - beginning with telegraphy and moving from radio to television solved simultaneously the problems of rapid production and distribution."

Teknologi dan atau media tidak lagi hanya sekadar alat. Ia memiliki peranan yang penting yang tak dapat diabaikan. Keputusan untuk memilih media tertentu akan berujung pada dampak apa yang akan timbul. McLuhan benar ketika ia mengatakan 'the medium is the message'.

Determinisme media memiliki ciri, seperti dikutip dari Dave's Page for Technological and Media Determinsim, sebagai berikut :

(1) Media destroy time and space.

(2) The medium is the message.

(3) To create a new medium, the old one has to go.

(4) Whatever media is predominant, then that is what the people will be.

(5) There exists a drive toward efficiency and speed

(6) Childhood is going (disappearance the limit between childhood and adult). 
Meskipun demikian, ada beberapa kritikus yang sependapat dengan argumen McLuhan tentang determinisme media. Salah satunya adalah Evans (1998) yang mengatakan,

Marshal McLuhan and Neil Postman are quick to promote the idea that print allows logical and analytical thinking to occur." Furthermore he says, " It is safe to assume that printing makes knowledge accessible to all, although it needs to be accompanied with necessary cultural and political conditions making literacy compulsory for all. However, this does not necessarily lead to society that is much more knowledgeable than one that uses oral communication as its foundation.

\section{Analisis}

Bimber (1995) menyebutkan adanya tiga wajah determinisme teknologi; (1) normatif; (2) akibatyang-tak-diinginkan; dan (3) nomologis. Pandangan normatif meyakini bahwa teknologi adalah produk intelek masyarakat, dan oleh karena itu, teknologi memiliki peranan yang penting di dalam masyarakat bila makna kulutral dan politik dilekatkan padanya. Pandangan akibat-yang-takdiinginkan ini percaya bahwa teknologi, setidaknya pada beberapa bagiannya, bersifat otonom. Otonomi teknologi ini berkaitan dengan beberapa akibat teknologi yang tidak dapat diramalkan sebelumnya. Sedangkan pandangan nomologis meyakini bahwa masa depan ditentukan oleh perkembangan teknologi.

Hanya pandangan nomologis inilah yang dapat dianggap sebagai determinisme teknologi yang sebenarnya, dalam arti adanya hubungan sebab-akibat antara masyarakat dan teknologi. Sementara itu, pandangan normative dan akibatyang-tak-diinginkan meyakini bahwa tidak alasan yang mencukupi untuk percaya pada hubungan sebab-akibat antara teknnologi dan masyarakat.

Baik mereka yang mendukung maupun yang menentang determinisme teknologi, benar ketika mereka meyakini bahwa teknologi adalah produk masyarakat. Tetapi, mereka berbeda dalam hal, sejauh mana teknologi berkaitan dengan masyarakat. Sekarang pertanyaannya adalah siapa yang lebih berpengaruh terhadap perubahan sosial, teknologi, atau masyarakat.

Huges (1995: 112) memberikan jawaban yang menarik atas pertanyaannya ini. Dia menawarkan konsep, 'momentum teknologi' di mana, " a technological system can be both a cause and an effect; it can shape or be shaped by society. As they grow larger and more complex, system tend to be more shaping of society and less shaped by it. Therefore, the momentum of technological system is a concept that can be located somewhere between the poles of technical determinism and social constructivism."

Sedangkan menurut Jhally (1993), "Technology is a social construct and serves the prevailing system of social power, though it often contributes to changes in the organization and distribution of that power."

Dalam kaitan dengan konsep otonomi teknologi, Chandler (Technological or Media Determinism: Technological Autonomy) mengatakan, "Rather than as product of society and an integral part of it, technology is presented as an independent, self-controlling, self-determining, selfgenerating, self-propelling, self-perpetuating and self-expanding force. It is seen as out of human control, changing under its own momentum and' blindly'shaping society."

Lebih jauh lagi, Chandler berargumen bahwa Thomas Carlyle, Charles Dickens, Ralph Waldo Emerson, Nathaniel Hawthorne, Henry Thoreau, Mark Twain, Henry Adams, John Ruskin, William Morris, George Orwell, Kurt Vonnegut, termasuk mereka yang mengkhawatirkan dampak otonomi teknologi.

Kecemasan mereka terhadap otonomi teknologi, sulit untuk dipahami karena teknologi adalah aspek praktis dari ilmu pengetahuan. Sedangkan ilmu pengetahuan adalah prinsipprinsip umum yang diturunkan dari hukum alam melalui metode ilmiah, sehingga secara ringkas dapat dikatakan bahwa teknologi adalah pemanfaatan hukum alam bagi kehididupan seharihari. Hal ini berarti bahwa secara ontologis, teknologi adalah bebas nilai, karena pada dasarnya ia adalah aspek praktis dari ilmu pengetahuan. Meskipun demikian, dari sudut pandang 
aksiologis, teknologi tidaklah bebas nilai. Menurut Chandler (Technological or Media Determinism: Technological Neutrality), "Neil Postman insists that the uses made technology are largely determined by the structure of technology itself,"

Lebih jauh Chandler mengatakan bahwa argumen Postman bagi bias ideologis media adalah:

(1) because of the symbolic forms in which information is encoded, different media have different intellectual and emotional biases;

(2) because of the accessibility and speed of their information, different media have different political biases;

(3) because of their physical form, different media have different sensory biases;

(4) because of the condition in which we attend to them, different media have different social biases;

(5) because of their technical and economies structure, different media have different content biases.

\section{Kesimpulan}

Untuk menyimpulan perdebatan di sekitar determinisme teknologi ini, pendapat Lim (2003) layak untuk diperhatikan. Lim mengatakan, "Both technology and culture involve continuous process of change, adaptation and accommodation and are both symbiotic and reliant on each other for the simple fact that the human factor lies behind the production and consumption of technology, through combination of people's motivations, skills and communication networks."

Lim benar ketika ia mengatakan bahwa teknologi dan budaya saling bergantung. Mengabaikan salah satunya akan menghasilkan pemahaman yang kurang memadai terhadap determinisme teknologi.

Pada dasarnya, kesenjangan antara pendukung dan penentang determinisme teknologi tidaklah terlalu lebar. Mereka masih berada pada perahu yang sama. Keduanya mempercayai bahwa teknologi dan masyarakat saling mempengaruhi, tetapi mereka berbeda dalam tingkat perubahan yang dihasilkan oleh teknologi. Dan hubungan antara teknologi dan masyarakat pada tataran praktis pada dasarnya lebih menyerupai kontinum. Determinisme teknologi berada di dalam kontinum ini.

Sebagai sebuah produk intelektual masyarakat, teknologi dibentuk oleh masyarakat, tetapi ketika teknologi itu telah berkembang, masyarakat harus menyesuaikan dirinya terhadap teknologi tersebut. Sementara itu, dalam kaitan antara teknologi dan masyarakat Pannabnecker (1990) berpendapat " "These relationships are too complex to be understood solely as a set of causes and effects in which technology is the source of the causes and society the context of impacts. The immediate task is not, however, to find a single alternate metaphor but to recognize that there are different ways of approaching the study of technology and society."

\section{Daftar Pustaka}

Bimber, Bruce. 1995. "Three Faces of Technological Determinism" in Smith, Merritt Roe and Marx, Leo (eds) Does Technology Drive History: The Dilemma of Technological Determinism, second printing, The MIT Press, Cambridge, Massachusetts.

Chandler, Daniel “Technological or Media Determinism: Technological Autonomy," viewed 11 May 2004. http://www.aber.ac.uk/media/ Documents/tecdet/tdet06.html.

Chandler, Daniel 'Technological or Media Determinism: Technological Neutrality, viewed 11 May 2004. http://www.aber.ac.uk/media/ Documents/tecdet/tdet08.html.

Cooper, Simon. 2002. Technoculture and Critical Theory: In the service of the machine?, Routledge, London.

Dave's Page for technological and Media Determinism, viewed 2 June 2004. http:// users.marshall.edu/ anders $45 /$ determinis.htm 
Evans, Daniela Lesley. 1998. “A Critical Examination of Claims Concerning The 'Impact' of Print," http://www.aber.ac.uk/media/Students/dle9701.html viewed 2 June 2004.

Feenberg, Andrew c. 1996. "From Essentialism to Constructivism: Philosophy of Technology at the Crossroads," http://wwwrohan.sdsu.edu/faculty/feenberg/talk4.html viewed 11 May 2004.

Feenberg, Andrew c. 1996. "Critical Theory of Technology,” http://www-rohan.sdsu.edu/ faculty/feenberg/CRITSAM2.HTML viewed 11 May 2004.

Galvin, Michael. 1994. "Vectory in The Gulf: Technology, Communication and War," in Green, Lelia and Guinery, Roger (eds) Framing Technology: Society, Choice and Change, Allen \& Unwin, NSW.

Hughes, Thomas P. 1995. “Technological Momentum," in Smith, Merritt Roe and Marx, Leo (eds) Does Technology Drive History: The Dilemma of Technological Determinism, second printing, The MIT Press, Cambridge, Massachusetts.
Jhally, Shut. 1993. "Communication and the materialist conception of History: Marx, Innis and technology" Continuum: The Australian Journal of Media \& Culture, Vol. 7, No 1, 1993 http:/ /wwwmcc.murdoch.edu.au/ReadingRoom/7.1/ Jhally.html viewed 2 June 2004.

Lim, Sharon Y.P. c. 2003. "Technology and Culture: A quintessential human activity," http://www. und p.org.my/facts heet/docs/ ICTgWriting_2_TechnologyAndCulture, 15Oct03.pdf viewed 11 May 2004.

Mesthene, Emmanuel G.. 1970. Technological Change: Its Impact on Man and Society, Harvard University Press, Cambridge, Massachusetts.

Pannabecker, John R. c. 1990. “Technological Impacts and Determinism in Technology Education: Alternate Metaphors from Social Constructivism," http://scholar.lib.vt.edu/journals/JTE/v3n1/pdf/pannabecker.pdf viewed 11 May 2004.

Winston, Morton. 1999. "Children of innovation," in Winston, Morton E. and Edelbach, Ralph D. (eds)' in Society, Ethics, and Technology. Belmont, CA.: Wadsworth. 
